Original Article

\title{
Effect of Accuracy and Muscle Strength Training on the Result of Shooting Throws in Petanque
}

\author{
Benny Badaru', Muhammad Rachmat Kasmad², Juhanis ${ }^{3}$, Nur Indah Atifah Anwar ${ }^{4}$ \\ 1,2,3,4 Pendidika Jasmani kesehatan dan Rekreasi, Universitas Negeri Makassar, Indonesia \\ benny.b@unm.ac.id ${ }^{1}$,m.rachmat.k@unm.ac.id ${ }^{2}$,juhanis@unm.ac.id ${ }^{3}$,indahatifah@yahoo.com
}

\begin{abstract}
ABSTRAK
Penelitian ini bertujuan untuk mengetahui: Pengaruh latihan manakah yang lebih baik, antara latihan ketepatan dan latihan kekuatan lengan terhadap hasil lemparan shooting pada atlet petanque. Penelitian ini merupakan penelitian eksperimen dengan bentuk desain one - Group Pretes -Postest Design. Populasi dan sampel dalam penelitian ini adalah atlet petanque sulawesi selatan dengan jumlah 16 atlet, tehnik penentuan sample menggunakan sampel jenuh.Tehnik analisis data di gunakan adalah statistik deskriptif. Hasil penelitian menunjukkan bahwa: (1) kelompok perlakuan kekuatan yang di latih dengan latihan push up,berpengaruh secara signifikan terhadap hasil shooting atlet petanque sulawesi selatan,pengaruh terlihat dari peningkatan hasil dari tes awal ke tes akhir sebesar 19,147. (2) kelompok perlakuan yang di latih dengan latihan melempar bosi ke ban dan melempar bosi dengan rintangan balok berpengaruh secara signifikan terhadap hasil shooting atlet petanque Sulawesi Selatan, sehingga pengaruh peningkatan terlihat dari hasil tes awal ke tes akhir sebesar 6,206. Hal ini dapat disimpulkan bahwa latihan kekuatan otot lengan lebih signifikan pengaruhnya terhadap lemparan shooting di bandingkan dengan latihan ketepatan ,terlihat dari besarnya nilai peningkatan yang diperoleh dari kelompok eksperimen kekuatan otot lengan
\end{abstract}

Kata Kunci: Latihan, Ketepatan, kekuatan, shooting dan petanque.

\section{ABSTRACT}

This study aims to determine: The effect of which exercise is better, between precision training and arm strength training on the results of shooting shots at petanque athletes. This research is an experimental research in the form of one-group pretest-postest design design. The population and sample in this study were South Sulawesi athlete athletes with a total of 16 athletes, the technique of determining samples using saturated samples. The data analysis technique used was descriptive statistics. The results showed that: (1) the strength treatment group trained by push up exercises significantly influenced the shooting results of South Sulawesi petanque athletes, the effect seen from the increase in results from the initial test to the final test was 19,147. (2) the treatment group trained by throwing bosi on the tires and throwing bosi with beam barriers had a significant effect on the shooting results of South Sulawesi petanque athletes, so that the effect of improvement was seen from the results of the initial test to the final test of 6.206. The conclusion of the study is that arm muscle strength training has a more significant effect on shooting throw compared to accuracy training, it can be seen from the magnitude of the increase in value obtained from the arm muscle strength experimental group

Keywords: Exercise, Accuracy, strength, shooting and petanque. 
57 | Benny Badaru', Muhammad Rachmat Kasmad ${ }^{2}$, Juhanis $^{3}$, Nur Indah Atifah Anwar $^{4}$

Effect of Accuracy and Muscle Strength Training on the Result of Shooting Throws in Petanque

Received: 02-06-2021; Accepted: 14-06-2021; Published: 20-06-2021

(c) 2021 Universitas Suryakancana

e-ISSN: 2721-7175(online) p-ISSN: 2089-2341 (cetak)

\section{PENDAHULUAN}

Olahraga permainan Petanque merupakan olahraga yang baru masuk di Indonesia,meski tergolong olahraga baru di Indonesia. Petanque sebenarnya termasuk olahraga yang sudah ada sejak dahulu kala. Pada Sea Games 2011 dan 2013 team cabang olahraga Petanque Indonesia belum bisa berbicara banyak. Salah satu faktor penyebabnya adalah karena belum tersosialisasikan cabang olahraga ini secara merata ke Provinsi - Provinsi yang ada di Indonesia. Olahraga Petanque tidak menuntut kondisi fisik yang tinggi seperti cabang olahraga lainnya,dengan demikian olahraga ini dapat di lakukan oleh anak anak ,remaja,dewasa sampai orang tua dan dapat di mainkan di mana saja dan oleh siapa saja sehingga olahraga ini dapat pula di jadikan sebagai alternatif pilihan dalam olahraga rekreasi dan kesehatan. Olahraga Petanque adalah suatu bentuk permainan boules yang bertujuan melempar bosi sedekat mungkin ke boka sebagai sasaran dengan ke dua kaki berada di dalam lingkaran ,jenis lemparan dalam Petanque ada dua yakni pointing dan shooting yang di mana kedua tehnik ini memiliki peran masing masing, pointing bertujuan mendekatankan bola ke boka sasaran sedangkan shooting jenis lemparan untuk menjauhkan bola lawan dari boka atau target (Parlindungan et al., 2019).

Petanque masuk ke Sulawesi selatan pada tanggal 22 maret 2016, sebagian atlet Petanque Sulawesi Selatan adalah mahasiswa FIK UNM walaupun tergolong baru olahraga ini di Sulawesi Selatan,tetapi beberapa atletnya telah mengikuti kejuaraan yang berlevel Nasional dan bahkan Internasional seperti Kejurnas Petanque antar Mahasiswa Se Indonesia di Tasikmalaya , Jawa Barat tahun 2016, Pekan Olahraga Nasional XIX di Bekasi, Jawa Barat tahun 2016 (Juhanis \& Nur, 2019). Faktor penting yang berpengaruh serta yang dibutuhkan oleh pemain Petanque adalah tehnik dasar bermain Petanque yang harus di kuasai oleh pemain,bukan hanya tehnik dasar yang perlu di kuasai seorang pemain tapi juga memerlukan kondisi fisik yang baik untuk melempar .setiap olahraga prestasi memiliki komponen kondisi fisik yang berbeda - beda tergantung dari kebutuhan masing-masing cabor. Faktor fisik mempunyai peranan penting yang sangat utama, hal ini berarti keberadaan fisik yang baik merupakan modal utama bagi pemain dalam meraih prestasi. Dukungan fisik 
58 | Benny Badaru', Muhammad Rachmat Kasmad ${ }^{2}$, Juhanis ${ }^{3}$, Nur Indah Atifah Anwar $^{4}$

Effect of Accuracy and Muscle Strength Training on the Result of Shooting Throws in Petanque

yang baik akan meningkatkan prestasi seorang pemain bila program yang di berikan sesuai dengan kebutuhan yang di harapkan.

Atlet petanque sulawesi selatan sendiri sudah sering mengikuti kejuaraan namun hasilnya belum begitu memuaskan. Masalah-masalah yang dapat mempengaruhi di antaranya kualitas pelatih, sarana dan prasarana yang di miliki, dukungan dari pemerintah dan masyarakat serta kualitas pemain itu sendiri. Masalah terpenting dalam upaya peningkatan prestasi dalam petanque adalah peningkatan kualitas pembinaan dan pelatihan. Penguasaan tehnik dasar permainan petanque perlu di utamakan dalam rangka pencapaian prestasi yang optimal. Salah satu permasalahan yang penting dalam permainan petanque adalah tingkat penguasaan keterampilan tehnik dasar dalam petanque. Dalam hal ini adalah teknik dasar lemparan shooting.

Menurut (Lubis, 2019), shooting adalah jenis lemparan untuk mengusir bosi lawan dari boka target. Shooting merupakan salah satu nomor yang dipertandingan yang ada di cabang olahraga petanque dan bagian terpenting pada permainan petanque. Apabila dalam 1 tim kemampuan shooting atlet lemah, maka tim tersebut akan kesulitan dalam menyerang bola lawan. Shooting pada cabang Petanque memiliki pengaruh yang sangat besar terhadap suatu pertandingan, karena tidak mutlak seorang atlet hanya memiliki kemampuan pointing.

Pada nomor pertandingan shooting yang dilakukan pada jarak 6 meter, 7 meter, 8 meter, dan 9 meter dengan poin yang bisa diperoleh 0 poin, 1 poin, 3 poin, dan 5 point tiap shooting yang berhasil. Penembak hanya diberi kesempatan satu kali shooting tiap jarak disiplin yang diberikan. Menurut (Hermawan, 2012), berdasarkan tujuan mekanika utamanya permainan petanque termasuk kedalam cabang olahraga yang mempunyai tujuan mencapai ketepatan maksimal. Artinya lemparan yang dilakukan harus tepat mengenai sasaran tertentu untuk mendapatkan poin kemenangannya. Sehingga dari pernyataan tersebut maka ketepatan berpengaruh pada nomer lemparan shooting, semakin tepat lemparan pada hambatan yang diberikan maka semakin banyak poin yang didapatkan. Menghasilkan lemparan yang tepat pada sasaran dibutuhkan metode-metode yang tepat. Pelatih harus kreatif dalam memberikan program latihan kepada atletya. Selain itu komponen- komponen yang mempengaruhi keberhasilan shooting juga harus diperhatikan yaitu: Pegangan bola (teknik dalam memegang bosi), Posisi badan mengarah ke target (kelurusan badan 
59 | Benny Badaru', Muhammad Rachmat Kasmad ${ }^{2}$, Juhanis ${ }^{3}$, Nur Indah Atifah Anwar $^{4}$

Effect of Accuracy and Muscle Strength Training on the Result of Shooting Throws in Petanque

dengan target), Keseimbangan statis tungkai , Posisi badan yang rendah dan condong ke depan, Relase the ball (pelepasan bola) Follow through. (Sinaga, 2019).

Setiap atlet harus memiliki kemampuan shooting untuk menyempurnakan kemampuannya dalam bermain Petanque,seorang atlet pemula tidak di anjurkan untuk pertama kali latihan shooting, karena atlet pemula harus mengetahui tehnik dasar dalam melempar dalam olahraga Petanque. Tapi untuk mencapai suatu prestasi nomor shooting lah yang merupakan hal yang mutlak yang harus dikuasai oleh semua atlet Petanque baik pria maupun wanita. Sehingga tidak mudah menjadi seorang shooter karena pada nomor ini seorang atlet harus memiliki tingkat ketenangan, konsentrasi dan akurasi yang tinggi, dan nomor shooting merupakan nomor yang paling sulit di kuasai oleh atlet Petanque di Indonesia, bahkan hanya beberapa atlet yang mampu menguasai tehnik shooting, shooting ini adalah lemparan yang paling sulit butuh latihan bertahun-tahun untuk bisa menguasai tehnik ini ,sehingga di pertandingkan pula di nomor yang berbeda.Salah satu tehnik dasar dalam Petanque adalah melempar.Melempar merupakan salah satu tehnik yang paling penting dan yang paling banyak di gunakan di Petanque, maka tehnik melempar merupakan tehnik dasar dari permainan Petanque

Mengingat pentingnya keterampilan shooting tersebut,maka keterampilan shooting ini harus mendapatkan perhatian yang serius dalam pembinaan prestasi petanque. Setiap pemain perlu di latih keterampilan shooting. Demikian juga pada para atlet petanque Sulawesi Selatan, dalam rangka peningkatan prestasinya perlu di berikan latihan secara intensif dengan program latihan yang benar.Latihan yang di berikan harus memeperhatikan faktor kondisi fisik yang mempengaruhi shooting. Kemampuan shooting,sangat di pengaruhi oleh unsur kondisi fisik pemain. Unsur kondisi fisik yang mempengaruhi kemampuan shooting di antaranya kekuatan dan ketepatan.

Kekuatan merupakan kemampuan untuk mengeluarkan tenaga secara maksimal dalam satu usaha, kemampuan kekuatan berarti terjadinya kontraksi otot pada manusia (Chan, 2012). Kekuatan otot lengan sangat membantu pencapaian lemparan, untuk membentuk kekuatan otot lengan dapat dilatihkan salah satunya dengan latihan yaitu, latihan fisik baik itu latihan pull up menggunakan karet seperti lateks, dan latihan push up secara berirama cepat dan lambat (Faridhatunnisa \& Pratama, 2019). Maka dari itu pada cabang Petanque perlu adanya latihan untuk melatih kekuatan lengan salah satunya dengan latihan push up. Salah satu masalah dalam cabang olahraga ini dari 
60 | Benny Badaru', Muhammad Rachmat Kasmad ${ }^{2}$, Juhanis $^{3}$, Nur Indah Atifah Anwar $^{4}$

Effect of Accuracy and Muscle Strength Training on the Result of Shooting Throws in Petanque

hasil pengamatan peneliti yakni kekuatan yang di miliki sebagian atlet masih kurang sehingga pada saat melempar sasaran terkadang bola bola lepas di bawah, atau bola saat di lempar arahnya tidak sesuai keinginan,dan sering kali bola lemparan tidak sampai pada target jika jarak 9-10 meter ,itu semua di akibatkan kurangnya latihan kekuatan untuk memperkuat otot lengan sehingga pada saat melempar seperti melempar secara asal- asalan.

Di samping itu ada beberapa latihan yang berpengaruh besar terhadap lemparan yakni latihan ketepatan yang dimana ketepatan merupakan salah satu aspek kondisi fisik yang paling penting untuk keterampilan shooting. Salah satu faktor yang dapat mempengaruhi ketepatan dalam melakukan shooting pada cabang olahraga petanque sehingga tidak akurat dan tidak tepat diantaranya yaitu kurangnya kekuatan otot lengan (Setiawan \& Effendi, 2020). Mengapa seorang atlet Petanque harus menguasai ketepatan ini ? Karena tanpa latihan ketepatan secara berulang - ulang akan sulit mendapatkan lemparan yang maksimal sehingga tidak dapat melakukan tembakan dengan tepat sasaran. Hal ini merupakan masalah yang terdapat pada atlet petanque sulsel,kurangnya melakukan latihan lemparan yang sesuai dengan porsi shooting ,sehingga pada saat pertandingan sulit untuk melakukan shooting saat di perlukan dan suatu game.Di mana ketepatan merupakan kemampuan seorang atlet mengarahkan bola sampai pada target atau sasaran yang dituju dengan pendaratan yang baik serta sempurna. akurasi sangat berkaitan erat dengan ketepatan jarak titik tembak dan kekuatan tembakan, karena kemampuan seseorang untuk mengendalikan gerakangerakan bebas terhadap suatu sasaran.Oleh karena itu untuk memiliki lemparan dengan akurasi yang baik di perlukan banyak latihan melempar untuk memperkuat otot-otot lengan.

Berdasarkan fakta di lapangan, seperti yang terjadi pada atlet petanque sulsel dalam mengikuti kejuaraan ,menurut pengamatan peneliti atlet petanque sulsel memiliki kemampuan kekuatan dan ketepatan yang kurang efektif saat melakukan shooting.hal ini terlihat pada saat latihan dan bertanding,faktor kekuatan dan ketepatan yang masih kurang menjadi hal yang perlu di perbaiki saat melakukan shooting. Faktanya dari enam kejuaraan nasional yang pernah di ikuti pada nomor shooting atlet petanque sulsel hanya dua kali menyumbang medali,ini membuktikan bahwa perlu ada perhatian khusus terhadap atlet pada nomor shooting. Ada beberapa penelitian sebelumnya yang memiliki kemiripan seperti penelitian (Lubis \& Permadi, 2020) 
61 | Benny Badaru', Muhammad Rachmat Kasmad ${ }^{2}$, Juhanis ${ }^{3}$, Nur Indah Atifah Anwar $^{4}$

Effect of Accuracy and Muscle Strength Training on the Result of Shooting Throws in Petanque

dengan judul," Perbedaan Pengaruh Latihan Imagery Dan Tanpa Latihan Imagery Terhadap Peningkatan Kemampuan Shooting Game Atlet Petanque Undikma", penelitian (Agustini et al., 2018) dengan judul," Hubungan Kekuatan Otot Lengan Dan Koordinasi Mata Tangan Terhadap Ketepatan Shooting Dalam Olahraga Pétanque Di Klub Kota Sukabumi Tahun 2018”, penelitian (Tyas Agustina, 2017) dengan judul,” Hubungan antara tingkat konsentrasi terhadap hasil ketepatan shooting olahraga petanque pada peserta Unesa Petanque Club". Dari ketiga penelitian sebelumnya yang pernah dilakukan memang memiliki perbedaan. Sehingga penelitian yang dilakukan ini memiliki kebaharuan dalam cabang olahraga petanque.

Berdasarkan uraian latar belakang masalah yang telah di jelaskan di atas ,maka peneliti meras tertarik untuk mengadakan penelitian dengan judul "Pengaruh Latihan Kekuatan dan Ketepatan terhadap Hasil Shooting pada Atlet Petanque Sulawesi Selatan”. Berdasarkan penjelasan tersebut, penelitian ini memiliki urgensi yang sangat tinggi karena kurangnya penelitian yang serupa untuk meihat sampai sejauh mana efektifitas dari kedua latihan tersebut terhadap hasil lemparan shooting pada cabang olahraga petanque.

\section{METODE}

Metode yang digunakan dalam penelitian adalah eksperimen. Metode eksperimen digunakan untuk mencari pengaruh perlakuan tertentu terhadap yang lain dalam kondisi yang terkendalikan. Tempat penelitian dilaksanakan di Lapangan Petanque FIK UNM Makassar. Desain atau rancangan penelitian yang digunakan dalam penelitian ialah One-Group Pretest-Posttest Design.

\begin{tabular}{lcll}
\hline Subyek & Pretest & Perlakuan & Post test \\
\hline $\mathrm{R}$ & $\mathrm{O}_{1}$ & $\mathrm{P}$ & $\mathrm{O}_{2}$ \\
\hline
\end{tabular}

Gambar 1. Rancangan penelitian

Sumber : (Sugiyono, 2008)

Keterangan :

$\mathrm{O}_{1} \quad:$ Tes awal (pre test)

$\mathrm{P} \quad$ : Perlakuan

$\mathrm{O}_{2} \quad$ : Tes akhir (post test)

Desain dilakukan dengan mengukur subjek penelitian (pretest) sebelum diadakannya perlakuan (treatment) dan melakukan pengukuran kembali setelah diberi 
62 | Benny Badaru', Muhammad Rachmat Kasmad ${ }^{2}$, Juhanis ${ }^{3}$, Nur Indah Atifah Anwar $^{4}$

Effect of Accuracy and Muscle Strength Training on the Result of Shooting Throws in Petanque

perlakuan (posttest).Populasi dalam penelitian ini adalah seluruh atlet petanque Sulawesi Selatan yang pernah mengikuti kejuaraan nasional yang berjumlah 16 mahasiswa. Karena populasi kurang dari 100, maka peneliti menggunakan sampel populasi yaitu seluruh anggota populasi dijadikan sampel penelitian. Teknik pengambilan sampel menggunakan sampling jenuh yang dimana untuk menentukan jumlah sampel berdasarkan jumlah populasi yang di ambil sebagai sampel Teknik pengumpulan data menggunakan pengukuran. Adapun instrumen penelitian yang digunakan dalam penelitian adalah Tes Shooting olahraga petanque. Teknik analisis data menggunakan uji t.

\section{HASIL DAN PEMBAHASAN}

\section{Hasil Penelitian}

Hasil penelitian yang disajikan adalah hasil dari perhitungan yang telah dilakukan terhadap data yang telah dikumpulkan. Sesuai dengan rancangan penelitian yang digunakan, atlet diberikan tes awal (pretest) dengan instrumen tes shooting olahraga petanque dengan tujuan untuk mengetahui kemampuan awal atlet petanque dalam melakukan lemparan shooting pada cabang olahraga petanque, dengan kata lain, kemampuan tersebut merupakan kemampuan murni atlet sebelum peneliti melaksanakan penelitian atau sebelum memberikan perlakuan (treatment) berupa latihan ketepatan dan latihan kekuatan otot lengan pada atlet petanque Sulawesi Selatan. Tujuan diberikannya latihan ketepatan dan kekuatan otot lengan kepada atet petanque untuk meningkatkan keterampilan lemparan shooting, diharapkan dengan diterapkannya dengan baik pada saat latihan, dapat meningkatkan keterampilan lemparan shooting pada cabang olahraga petanque.

\section{Tabel 1 Deskripsi Data (Pretest) dan (Posttest)}

\begin{tabular}{lll}
\hline Uraian & Tes Awal (Pretest) & Tes Akhir (Posttest) \\
\hline Minimal & 10 & 20 \\
Maksimal & 17 & 29 \\
Rata-rata & 13,38 & 24,31 \\
\hline
\end{tabular}

Kemampuan lemparan shooting atlet petanque pada saat melakukan tes awal (pretest) 
63 | Benny Badaru', Muhammad Rachmat Kasmad ${ }^{2}$, Juhanis ${ }^{3}$, Nur Indah Atifah Anwar ${ }^{4}$

Effect of Accuracy and Muscle Strength Training on the Result of Shooting Throws in Petanque

yaitu sebesar 13,38. Sedangkan Kemampuan lemparan shooting atlet petanque pada saat melakukan tes akhir adalah sebesar 24,31. Sesuai dengan Tabel 1, didapatkan data bahwa maksimal hasil tes kemampuan lemparan shooting petanque (pretest) adalah skor maksimal 17 dan minimal 10, sedangkan maksimal hasil tes kemampuan lemparan shooting petanque (posttest) adalah skor maksimal 29 dan skor minimal 20, bahwa pelaksanaan latihan ketepatan dan kekuatan otot lengan dapat memberikan pengaruh yang signifikan terhadap keterampilan lemparan shooting olahraga petanque pada atlet Petanque Sulawesi Selatan.

Untuk membuktikan adanya perubahan keterampilan lemparan shooting pada cabang olahraga petanque, dalam usaha meneliti manakah yang lebih baik metode latihan antara latihan ketepatan dan kekuatan otot lengan untuk meningkatkan keterampilan lemparan shooting olahraga petanque., akan diadakan perhitungan statistik dengan menggunakan rumus uji $\mathrm{t}$ antara tes awal dan tes akhir. Hasil perhitungan sebagai berikut.

Tabel 3. Hasil Uji T Kelompok latihan Kekuatan dan Ketepatan terhadap Hasil shooting pada atlet petanque sulawesi selatan.

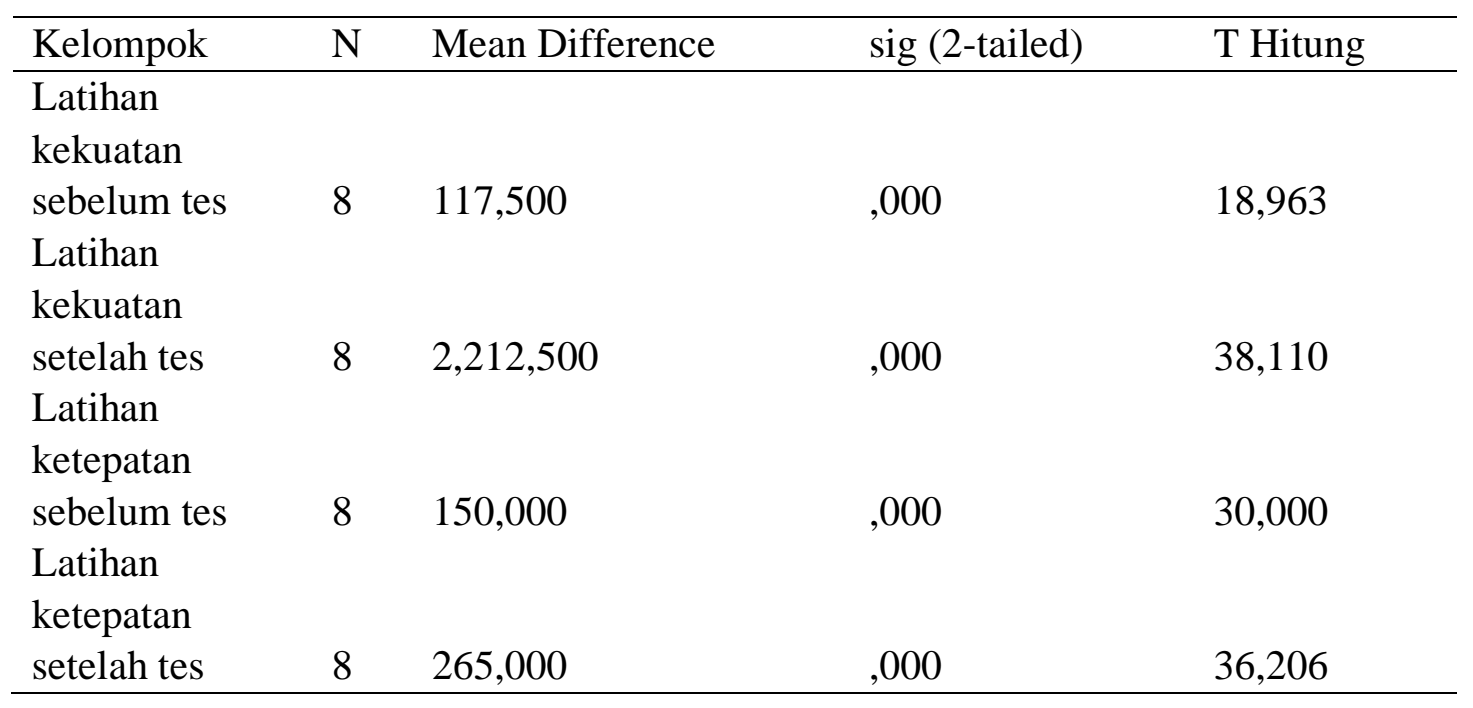

Melihat dari peningkatan t hitung pretest ke postest maka dapat di ketahui latihan kekuatan dengan nilai peningkatan t hitung 19,147, lebih baik dibandingkan dengan latihan ketepatan yang dengan peningkatan 6,206. Dengan peningkatan yang signifikan maka dapat disimpulkan latihan kekuatan lebih berpengaruh dari pada latihan ketepatan. 
64 | Benny Badaru', Muhammad Rachmat Kasmad ${ }^{2}$, Juhanis $^{3}$, Nur Indah Atifah Anwar $^{4}$

Effect of Accuracy and Muscle Strength Training on the Result of Shooting Throws in Petanque

\section{Pembahasan}

Program latihan yang baik harus dapat memberikan teknik-teknik latihan yang secara fisiologis dapat meningkatkan kualitas fisik orang yang melakukan. Program latihan harus disusun berdasarkan prinsip-prinsip latihan. peningkatan dalam hal pemberian beban latihan harus disesuaikan dengan tingkat kemampuan anak dan dilakukan bertahap. Jika tidak disesuaikan dengan kemampuan seorang atlet maka akan berakibat yang negatif dan dapat menghambat pertumbuhan dan perkembangan atlet. Prinsip beban berlebihan dan frekuensi latihan merupakan elemen-elemen yang sangat dibutuhkan dalam menentukan intensitas yang tepat dalam program- program yang berhasil. Agar efektif, latihan harus dilakukan atas dasar keteraturan. Latihan yang berlebihan tanpa adanya waktu istirahat atau pemulihan dapat menyebabkan kerusakan pada kemampuan tubuh untuk menyesuaikan diri. Sangat diperlukan waktu istirahat antara hari-hari latihan sama pentingnya seperti latihan sebenarnya, tubuh membutuhkan waktu pemulihan kembali untuk membuang hasil sampah latihan dari otot dan mengambil zat-zat makan yang sangat penting untuk kelanjutan pertumbuhan otot.

Berdasarkan hasil analisis, menunjukkan bahwa ada pengaruh latihan kekuatan dan latihan ketepatan terhadap hasil shooting. Menurut Harsono (1988:47) "kekuatan sebagai energy untuk melawan suatu tahanan atau kemampuan untuk membangkitkan tegangan. Berdasarkan pendapat tersebut menunjukkan bahwa latihan kekuatan merupakan bentuk latihan yang dapat meningkatkan eksplosif otot pada tubuh yang akan mengarah pada kemampuan tehnik lemparan. Menurut (Sajoto, 1988) menyatakan bahwa ketepatan adalah "pengendalian gerak-gerak terhadap suatu sasaran. Sasaran ini dapat merupakan suatu jarak atau mungkin suatu objek yang harus di kenai dengan salah satu bagian tubuh. Ketepatan sangat diperlukan pada permainan Petanque seperti saat melakukan Shooting. Berdasarkan hasil uji hipotesis yang di lakukan ,.Hasil yang dari kekuatan di peroleh tersebut apabila di kaitkan dengan kerangka berfikir dan teori teori yang mendasarinya.Hal ini di jelaskan bahwa hasil shooting sebelum perlakuan dengan rata -rata tes awal sebesar 11,750 sedangkan setelah di beri perlakuan rata- rata tes akhir sebesar 22,125. Sehingga dapat di katakan bahwa terdapat peningkatan ratarata sebelum dan setelah di beri perlakuan latihan kekuatan terhadap hasil shooting. serta melihat dari kontribusi latihan kekuatan terhadap hasil shooting sebelum sebesar 
65 | Benny Badaru', Muhammad Rachmat Kasmad ${ }^{2}$, Juhanis $^{3}$, Nur Indah Atifah Anwar $^{4}$

Effect of Accuracy and Muscle Strength Training on the Result of Shooting Throws in Petanque

18,962 dan setelah dan setelah sebesar 38,110. Sedangkan hasil yang di peroleh dari hasil ketepatan tersebut apabila di kaitkan dengan kerangka berfikir dan teori teori yang mendasarinya.Hal ini di jelaskan bahwa hasil shooting sebelum perlakuan dengan rata -rata tes awal sebesar 15,000 sedangkan setelah di beri perlakuan rata- rata tes akhir sebesar 26,500. Sehingga dapat di katakan bahwa terdapat peningkatan ratarata sebelum dan setelah di beri perlakuan latihan ketepatan terhadap hasil shooting .serta melihat dari kontribusi latihan ketepatan terhadap hasil shooting sebelum sebesar 30,000 dan setelah dan setelah sebesar 36,206. Melihat dari peningkatan pretest ke postest maka dapat di ketahui latihan kekuatan dengan nilai peningkatan sebesar 19,147, lebih baik dibandingkan dengan latihan ketepatan yang dengan peningkatan sebesar 6,206. Dengan peningkatan yang signifikan maka dapat disimpulkan bahwa latihan kekuatan lebih berpengaruh dari pada latihan ketepatan.Alasannya karena melihat dari hasil penelitian latihan kekuatan lebih memperlihatkan peningkatannya di bandingkan ketepatan ,meski ke dua variabel sangat di perluhkan dalam cabang olahraga petanquetapi ada yang lebih dominan yakni latihan kekuatan yaitu push up. Terlihat jelas pula bahwa dengan jarak yang berbeda maka seorang atlet juga memiliki kemampuan kekuatan yang berbeda saat melempar,faktor lain pula yakni tinggi badan seorang atlet akan mempengaruhi pula kekuatan lemparan seorang atlet. Di mana kekuatan adalah komponen yang sangat penting guna meningkatkan kondisi fisik seseorang secara menyeluruh. Pembuktian dapat terlihat bahwa terjadi peningkatan latihan kekuatan dan ketepatan terhadap hasil shooting karena di adakannya latihan kekuatan yakni push up dan latihan ketepatan yakni memasukkan bola ke ban dan melempar dengan rintangan balok.

Dengan demikian ,latihan kekuatan yang di khususkan pada latihan push up sesuai dengan hasil penelitian lebih baik di gunakan untuk latihan shooting pada cabang olahraga petanque.Karena tanpa adanya latihan kekuatan yang cukup baik akan sangat susah bagi seorang atlet untuk menegembangkan kemampuannya karena jarak yang tidak selalu sama membutuhkan kekuatan lemparan yang besar pula di tambah lagi beban bola yang berat membuat para atlet harus memiliki kekuatan lemparan yang maksimal.Di tambah lagi jadwal pertandingan yang cukup lama membuat para atlet harus memiliki daya tahan kekuatan yang optimal di mana kemampuan otot untuk mengatasi tahanan dalam jangka waktu yang lama, Menurut Pekik (2002: 66-67) sehingga pada saat 
66 | Benny Badaru', Muhammad Rachmat Kasmad ${ }^{2}$, Juhanis $^{3}$, Nur Indah Atifah Anwar $^{4}$

Effect of Accuracy and Muscle Strength Training on the Result of Shooting Throws in Petanque

menampilkan permainannya mendapatkan hasil yang maksimal. Hasil penelitian memperkuat penelitian Fallo (2014: 1) yang menunjukkan bahwa terdapat hubungan positif yang signifikan antara kekuatan otot lengan dengan keterampilan servis atas bola voli. Hasil penelitian Iskandar (2016: 20) juga menunjukkan bahwa terdapat hubungan positif yang signifikan antara kekuatan otot lengan dan keterampilan servis atas bola voli.

\section{SIMPULAN}

Berdasarkan data hasil penelitian yang telah dilakukan, maka disimpulkan bahwa terdapat pengaruh signifikan antara latihan ketepatan dan kekuatan otot lengan terhadap keterampilan lemparan shooting olahraga petanque pada atlet Petanque Sulawesi Selatan. Hasil penelitian berimplikasi pada: (1) Berubahnya keterampilan atlet petanque Sulawesi Selatan dalam melakukan lemparan shooting dari latihan ketepatan dan latihan kekuatan otot lengan; (2) Timbulnya inisiatif dari pelatih untuk menerapkan pada program latihannya tentang latihan ketepatan dan latihan kekuatan lengan untuk meningkatkan keterampilan lemparan shooting ; dan (3) Timbulnya upaya untuk mengembangkan variasi-variasi latihan untuk meningkatkan keterampilan lemparan shooting yang memperhatikan berbagai aspek latihan kondisi fisik pendukung.

\section{DAFTAR PUSTAKA}

Agustini, D. K., Nugraheni, W., \& Maulana, F. (2018). Hubungan Kekuatan Otot Lengan dan Koordinasi Mata Tangan Terhadap Ketepatan Shooting dalam Olahraga Petanque di Klub Kota Sukabumi Tahun 2018.

Chan, F. (2012). Strength Training (Latihan Kekuatan). Cerdas Sifa Pendidikan, 1(1).

Faridhatunnisa, F., \& Pratama, A. K. (2019). Peningkatan Latihan Kekuatan Otot Lengan Terhadap Hasil Servis Atas Bola Voli. Jurnal Maenpo, 9(2), 76-82.

Hermawan, I. (2012). Gerak dasar permainan olahraga Petanque. Jakarta: Deputi Pemberdayaan olahraga Kemenpora.

Juhanis, J., \& Nur, M. (2019). Pelatihan teknik dasar dan sosialisasi peraturan permaian olahraga Petanque pada mahasiswa FIK UNM Makassar. Seminar Nasional Pengabdian Kepada Masyarakat, 2018(2).

Lubis, M. R. (2019). Perbedaan Latihan Shooting Menggunakan Penghalang Dan Tanpa Penghalang Terhadap Peningkatan Kemampuan Shooting Game Atlet Pemula Petanque IKIP Mataram. Proceeding National Conference: Education, Social Science, and Humaniora, 1(1), 287-300.

Lubis, M. R., \& Permadi, A. G. (2020). Perbedaan Pengaruh Latihan Imagery Dan Tanpa Latihan Imagery Terhadap Peningkatan Kemampuan Shooting Game Atlet Petanque Undikma. Jurnal Ilmiah Mandala Education, 6(1). 
67 | Benny Badaru', Muhammad Rachmat Kasmad², Juhanis ${ }^{3}$, Nur Indah Atifah Anwar ${ }^{4}$

Effect of Accuracy and Muscle Strength Training on the Result of Shooting Throws in Petanque

Parlindungan, H. D., Bangun, S. Y., \& Akhmad, I. (2019). Development of Petanque Training Pointing and Sport Shooting. 4th Annual International Seminar on Transformative Education and Educational Leadership (AISTEEL 2019).

Sajoto, M. (1988). Pembinaan kondisi fisik dalam olahraga. Jakarta: Depdikbud.

Setiawan, A., \& Effendi, F. (2020). Akurasi Smash Forehand Bulutangkis Dikaitkan dengan Kekuatan Otot Lengan dan Koordinasi Mata-Tangan. Jurnal MAENPO: Jurnal Pendidikan Jasmani Kesehatan dan Rekreasi, 10(1), 50-56.

Sinaga, F. S. G. (2019). Analysis biomechanics pointing dan shooting petanque pada atlet TC PON XX PAPUA. Sains Olahraga: Jurnal Ilmiah Ilmu Keolahragaan, 3(2), $66-75$.

Sugiyono. (2008). Metode penelitian pendidikan:(pendekatan kuantitatif, kualitatif dan R \& D). Alfabeta.

Tyas Agustina, A. (2017). Hubungan antara tingkat konsentrasi terhadap hasil ketepatan shooting olahraga petanque pada peserta Unesa Petanque Club. Jurnal Pendidikan Olahraga Dan Kesehatan, 5(3). 